\title{
A Survey of the Vitamin and Mineral Content in Milk from Yaks Raised at Different Altitudes
}

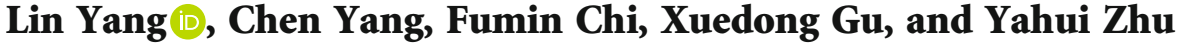 \\ College of Food Science, Tibet Agriculture \& Animal Husbandry University, Nyingchi 860000, China \\ Correspondence should be addressed to Lin Yang; yanglintibet@sina.com
}

Received 24 July 2021; Accepted 8 December 2021; Published 24 December 2021

Academic Editor: Hüseyin Bozkurt

Copyright (c) 2021 Lin Yang et al. This is an open access article distributed under the Creative Commons Attribution License, which permits unrestricted use, distribution, and reproduction in any medium, provided the original work is properly cited.

\begin{abstract}
In this study, the content of vitamins and of toxic and beneficial (macro- and micro-) minerals in milk from yaks raised at different altitudes $(3,215,4,340$, and $5,410 \mathrm{~m})$ was investigated. For comparison, the components in cow's milk were also measured. At higher altitudes, a significant $(P<0.05)$ increase in vitamin A and vitamin $\mathrm{E}$ was observed in the yak's milk, whereas the opposite was observed for vitamin $B_{1}$ and vitamin $B_{2}$. No significant statistical difference in vitamin $C, C a, P, N a$, $\mathrm{K}$, and $\mathrm{Mg}$ concentrations was observed in milk from yaks raised at different altitudes. The concentrations of $\mathrm{Zn}$ in milk from yaks raised at different altitudes showed no statistical difference, whereas the $\mathrm{Mn}$ and Fe concentrations in milk from yaks raised at 3,215 $\mathrm{m}$ were lower than those raised at higher altitudes. The concentrations of $\mathrm{Pb}$ and $\mathrm{Cd}$ in yak's milk did not exceed the maximum permissible concentrations (Codex Alimentarius Commission), whereas their concentrations were higher in milk from yaks raised at $3,215 \mathrm{~m}$ than at higher altitudes. These findings indicated that the contents of vitamins and minerals in yak milk varied in different altitudes.
\end{abstract}

\section{Introduction}

The yak (Bos grunniens) is a unique large ruminant livestock in the Qinghai-Tibet Plateau area, which has an altitude of 3,000 to $6,000 \mathrm{~m}$ and is located in western China. Yak's milk accounts for approximately $15 \%$ of China's milk production [1]. Yaks thrive in extremely harsh environments, under conditions including hypoxia, strong ultraviolet rays, minimal forage grass, and low temperatures [2]. Yak's milk is richer than cow's milk in the content of proteins, fat, and total solids; is easier to digest; and has lower allergenicity $[3,4]$. It is virtually the sole source of milk in the QinghaiTibet Plateau area.

Because yak's milk is an important resource to the local population, a more comprehensive understanding of yak's milk is necessary. Many studies have been performed on the main constituents of yak's milk, including the chemical composition, the protein or fatty acid distribution, and the microbiological compositions [5-8]. However, little information is available on the minor constituents of yak's milk, mainly vitamins and minerals [9]. These two minor constituents play important roles in the physiological development of humans.
Vitamins in milk mainly consist of $\mathrm{V}_{\mathrm{A}}, \mathrm{V}_{\mathrm{E}}$, and $\mathrm{V}_{\mathrm{B}}\left(\mathrm{V}_{\mathrm{B} 1}\right.$ and $\mathrm{V}_{\mathrm{B} 2}$ ), which cannot be manufactured within the body and must be obtained from the diet. In the Qinghai-Tibet Plateau area, yak's milk is virtually the sole vitamin source for the local population. Although some research has examined $V_{A}$ and $V_{c}$ [10], information on the other important vitamins $\left(\mathrm{V}_{\mathrm{B}}\right.$ and $\mathrm{V}_{\mathrm{E}}$ ) remains unavailable, and their differences in milk from yaks raised at different altitudes are unknown. Minerals in milk are divided into beneficial and toxic elements. The latter can cause metabolic disorders, even at low concentrations. The beneficial minerals have been examined in some studies [11, 12]; however, the toxic elements, particularly their differences depending on altitude, have not gained substantial research attention $[10,13,14]$.

The objective of this study was to investigate the content of vitamins and of toxic and essential (macro- and micro-) metals in milk from yaks raised at different altitudes.

\section{Materials and Methods}

2.1. Sample Collection. Three sampling sites were selected in the Tibet Autonomous Region in the Qinghai-Tibet Plateau 
area: Zhongsha village in Gongbo'gyamda $\left(29^{\circ} 14^{\prime} 47^{\prime \prime} \mathrm{N}\right.$ and $93^{\circ} 25^{\prime} 27^{\prime \prime} \mathrm{E}, 3,215 \mathrm{~m}$ in altitude), Gongtang village in Damxung county $\left(30^{\circ} 51^{\prime} 16^{\prime \prime} \mathrm{N}\right.$ and $91^{\circ} 05^{\prime} 29^{\prime \prime} \mathrm{E}, 4,340 \mathrm{~m}$ in altitude), and Duoma village in Shuanghu county $\left(31^{\circ} 10^{\prime} 08^{\prime \prime}\right.$ $\mathrm{N}$ and $84^{\circ} 52^{\prime} 17^{\prime \prime} \mathrm{E}, 5,410 \mathrm{~m}$ in altitude), with annual average temperatures of $3,1.7$, and $-5.5^{\circ} \mathrm{C}$, respectively.

At each sampling site, 70 lactating yaks were chosen according to their ages (5-7 years), group sizes (2-4), and milk lactation stages (50-100 days after the beginning of lactation), at which the yield of milk is highest. Each milk sample was placed into a $100 \mathrm{~mL}$ plastic tube. To inhibit microbial growth, $0.03 \%$ sodium azide was added to the samples. The samples were frozen and stored at $-20^{\circ} \mathrm{C}$ before analysis.

For comparison, 15 cow's milk samples were collected from Xuanhan County in the city of Dazhou, Sichuan Province $\left(31^{\circ} 75^{\prime} 09^{\prime \prime} \mathrm{N}\right.$ and $107^{\circ} 96^{\prime} 42^{\prime \prime} \mathrm{E}, 1,082 \mathrm{~m}$ in altitude), which has an annual average temperature of $21.4^{\circ} \mathrm{C}$. The cows were fed $75 \%$ forage and $25 \%$ crop residues year round.

\subsection{Determination of General Chemical Composition. The} fat content in milk was determined according to GB 5413.3-2010 [15]. Lactose content was determined according to GB 5009.8-2016 [16]. Total solids in milk were measured after treatment at $105^{\circ} \mathrm{C}$ for $5 \mathrm{~h}$. The protein content was determined with the Kjeldahl method and calculated from the nitrogen content in milk with a 6.38 conversion factor.

2.3. Determination of Vitamin. The method of GB 5009.822016, with slight modification, was applied to determine the $\mathrm{V}_{\mathrm{A}}$ and $\mathrm{V}_{\mathrm{E}}$ content [17]. Briefly, $3 \mathrm{~mL}$ of the sample was added into a glass tube, and this was followed by addition of $6 \mathrm{~mL}$ ethanol and $3 \mathrm{~mL}$ of $8.9 \mathrm{~mol} \mathrm{~L}^{-1} \mathrm{NaOH}$ solutions. After incubation in a water bath for $30 \mathrm{~min}$, the samples were cooled in an ice bath, and $20 \mathrm{~mL}$ of $40 \%$ diethyl ether and $60 \%$ petroleum ether mixture (containing $0.01 \%$ butylated hydroxytoluene) was added. After samples were vortexed for $3 \mathrm{~min}, 20 \mathrm{~mL}$ of ice water was added into the tubes, which were then inverted 20 times. Then, the samples were centrifuged at $3000 \mathrm{~g}$ for $20 \mathrm{~min}$ (H1-16KR, Hunan Kecheng Instrument Equipment Co., Ltd., China). The fatty layer was dried under vacuum at $38^{\circ} \mathrm{C}$ with a rotary evaporator (RE-2000A, Shanghai Yarong Co., Ltd., China). Finally, the samples were dissolved in methanol. The content of $\mathrm{V}_{\mathrm{A}}$ and $\mathrm{V}_{\mathrm{E}}$ was determined with high-performance liquid chromatography (HPLC, Agilent 1100 Series), by using a C18 chromatographic column (Zorbax Eclipse XDB-C18, $150 \times 4.6 \mathrm{~mm}, 5 \mu \mathrm{m})$. The eluent was a methanol and water mixture $(95: 5)$. The flow rate was $1.0 \mathrm{~mL} \mathrm{~min}^{-1}$. The wavelengths for $V_{A}$ and $V_{E}$ were 323 and $292 \mathrm{~nm}$, respectively.

The content of $\mathrm{V}_{\mathrm{B} 1}$ and $\mathrm{V}_{\mathrm{B} 2}$ was measured according to a previously reported method [18]. The chromatographic column and HPLC equipment were the same as those used for $\mathrm{V}_{\mathrm{A}}$ and $\mathrm{V}_{\mathrm{E}}$. The eluent consisted of $20 \%$ methanol, $0.3 \%$ triethylamine, and $2.6 \%$ glacial acetic acid. The wavelengths for $V_{B 1}$ and $V_{B 2}$ were 246 and $268 \mathrm{~nm}$, respectively. The method of GB 5413.18-2010 was applied to determine the $\mathrm{V}_{\mathrm{c}}$ content [19]. $\mathrm{V}_{\mathrm{c}}$ can be oxidized into dehydroascorbic acid. Dehydroascorbic acid can react with o-phenylenedi-
TABle 1: Composition (\%) of milk from yaks raised at different altitudes.

\begin{tabular}{lcccc}
\hline Component & \multicolumn{5}{c}{ Altitude } \\
& $3,215 \mathrm{~m}$ & $4,340 \mathrm{~m}$ & $5,410 \mathrm{~m}$ & Cow's milk \\
\hline Total solids & $16.0 \pm 1.6^{\mathrm{b}}$ & $17.4 \pm 1.6^{\mathrm{c}}$ & $18.8 \pm 1.6^{\mathrm{d}}$ & $13.1 \pm 0.7^{\mathrm{a}}$ \\
Fat & $5.3 \pm 0.4^{\mathrm{b}}$ & $6.7 \pm 0.7^{\mathrm{c}}$ & $7.0 \pm 0.9^{\mathrm{c}}$ & $4.1 \pm 0.6^{\mathrm{a}}$ \\
Protein & $5.0 \pm 0.7^{\mathrm{b}}$ & $5.2 \pm 0.3^{\mathrm{b}}$ & $5.8 \pm 0.5^{\mathrm{b}}$ & $3.4 \pm 0.4^{\mathrm{a}}$ \\
Lactose & $4.9 \pm 0.5^{\mathrm{b}}$ & $5.3 \pm 0.3^{\mathrm{b}}$ & $5.7 \pm 0.4^{\mathrm{b}}$ & $5.1 \pm 0.3^{\mathrm{a}}$ \\
\hline
\end{tabular}

Values are mean \pm standard deviation; means with different superscript letters within the same row are significantly different $(P<0.05)$.

amine, thus forming fluorescent compounds, which were detected with a fluorospectrophotometer (RF-6000, Shimadzu, Kyoto, Japan).

2.4. Determination of Minerals. One gram of raw yak's milk was added into $20 \mathrm{~mL}$ nitric acid and was then digested for $15 \mathrm{~min}$ at $150^{\circ} \mathrm{C}$ in a microwave digestion system (MK-3, Xinyi Microwave Chemical Science and Technology Ltd., Shanghai, China). After being cooled to room temperature, the samples were diluted to $100 \mathrm{~mL}$ with deionized water.

An inductively coupled plasma optical emission spectrophotometer (iCAP 6000, Thermo Scientific, Waltham, USA) was used to measure the content of iron $(\mathrm{Fe})$, calcium $(\mathrm{Ca})$, copper $(\mathrm{Cu})$, sodium $(\mathrm{Na})$, potassium $(\mathrm{K})$, manganese $(\mathrm{Mn})$, magnesium $(\mathrm{Mg})$, zinc $(\mathrm{Zn})$, and phosphorus $(\mathrm{P})$. An atomic absorption spectrometer (TAS-990, General Analysis Instruments Co. Ltd., Beijing, China) was used to determine the content of cadmium $(\mathrm{Cd})$ and lead $(\mathrm{Pb})$.

2.5. Statistical Analysis. The experiments were performed in at least triplicate. Analysis of variance was used to determine the significance of differences among treatments, with $P<$ 0.05 indicating significance.

\section{Results}

3.1. General Composition. The content of total solids and fat in yak's milk increased with increasing altitude, whereas the protein and lactose content showed no statistical differences among altitudes. In yak's milk, all components were higher than those in cow's milk (Table 1). This result was consistent with those reported by Li et al. [20].

3.2. Vitamin Content. Vitamin $\mathrm{A}$ and vitamin $\mathrm{E}$ are found in different forms, but only retinol and $\alpha$-tocopherol are considered important [21], because they exhibit higher biological activity than the other forms of vitamins A or vitamin $\mathrm{E}$, respectively. The content of water-insoluble vitamins A (retinol) and vitamin E ( $\alpha$-tocopherol) in milk from yaks raised at different altitudes is shown in Table 2. At higher altitudes, a significant $(P<0.05)$ increase in vitamin $\mathrm{A}$ and vitamin $\mathrm{E}$ was observed in the yak's milk. Vitamin A cannot be synthesized by animals and must be obtained exogenously. $\beta$-Carotene, the main precursor of vitamin $A$, has been found to increase with altitude in pasture [22], thus potentially explaining why the vitamin A content is positively associated with altitude. Vitamin E decreases oxygen 
TABLE 2: Content of vitamins in milk from yaks raised at different altitudes.

\begin{tabular}{lcccc}
\hline & & Altitude & & \\
& $3,215 \mathrm{~m}$ & $4,340 \mathrm{~m}$ & $5,410 \mathrm{~m}$ & Cow's milk \\
\hline Vitamin A (mg/L) & $0.45 \pm 0.19^{\mathrm{b}}$ & $0.78 \pm 0.27^{\mathrm{c}}$ & $0.74 \pm 0.24^{\mathrm{c}}$ & $0.16 \pm 0.06^{\mathrm{a}}$ \\
Vitamin E (mg/L) & $1.82 \pm 0.43^{\mathrm{b}}$ & $1.97 \pm 0.51^{\mathrm{bc}}$ & $2.33 \pm 0.49^{\mathrm{c}}$ & $1.37 \pm 0.31^{\mathrm{a}}$ \\
Vitamin $_{1}(\mathrm{mg} / \mathrm{L})$ & $4.15 \pm 1.68^{\mathrm{c}}$ & $2.14 \pm 0.69^{\mathrm{b}}$ & $2.81 \pm 0.83^{\mathrm{b}}$ & $0.85 \pm 0.32^{\mathrm{a}}$ \\
Vitamin B $_{2}(\mathrm{mg} / \mathrm{L})$ & $9.71 \pm 2.83^{\mathrm{c}}$ & $5.24 \pm 1.49^{\mathrm{b}}$ & $5.72 \pm 1.64^{\mathrm{b}}$ & $1.91 \pm 0.56^{\mathrm{a}}$ \\
Vitamin C (mg/L) & $32.80 \pm 9.03^{\mathrm{c}}$ & $37.32 \pm 11.07^{\mathrm{bc}}$ & $37.75 \pm 8.03^{\mathrm{b}}$ & $21.51 \pm 6.14^{\mathrm{a}}$ \\
\hline
\end{tabular}

Values are mean \pm standard deviation; means with different superscript letters within the same row are significantly different $(P<0.05)$.

TABle 3: Content of minerals in milk from yaks raised at different altitudes.

\begin{tabular}{lcccc}
\hline & & Altitude & & Cow's milk \\
\hline $\mathrm{Ca}(\mathrm{mg} / \mathrm{L})$ & $3,215 \mathrm{~m}$ & $4,340 \mathrm{~m}$ & $5,410 \mathrm{~m}$ & $1137.2 \pm 162.5^{\mathrm{a}}$ \\
$\mathrm{P}(\mathrm{mg} / \mathrm{L})$ & $1417.8 \pm 284.7^{\mathrm{b}}$ & $1451.9 \pm 156.3^{\mathrm{b}}$ & $1564.5 \pm 244.9^{\mathrm{b}}$ & $928.4 \pm 87.1^{\mathrm{a}}$ \\
$\mathrm{Na}(\mathrm{mg} / \mathrm{L})$ & $1034.0 \pm 173.2^{\mathrm{b}}$ & $1155.1 \pm 193.1^{\mathrm{b}}$ & $1186.9 \pm 211.6^{\mathrm{b}}$ & $379.1 \pm 48.7^{\mathrm{a}}$ \\
$\mathrm{K}(\mathrm{mg} / \mathrm{L})$ & $353.8 \pm 62.4^{\mathrm{a}}$ & $374.8 \pm 78.3^{\mathrm{a}}$ & $342.9 \pm 69.0^{\mathrm{a}}$ & $1427.9 \pm 233.2^{\mathrm{a}}$ \\
$\mathrm{Mg}(\mathrm{mg} / \mathrm{L})$ & $1577.1 \pm 375.7^{\mathrm{a}}$ & $1597.9 \pm 469.9^{\mathrm{a}}$ & $1537.9 \pm 445.1^{\mathrm{a}}$ & $109.6 \pm 28.2^{\mathrm{a}}$ \\
$\mathrm{Cu}(\mu \mathrm{g} / \mathrm{L})$ & $175.8 \pm 38.2^{\mathrm{b}}$ & $159.1 \pm 33.0^{\mathrm{b}}$ & $101.7 \pm 25.1^{\mathrm{b}}$ & $173.8 \pm 42.5^{\mathrm{a}}$ \\
$\mathrm{Fe}(\mu \mathrm{g} / \mathrm{L})$ & $159.1 \pm 38.1^{\mathrm{a}}$ & $92.7 \pm 23.8^{\mathrm{b}}$ & $986.1 \pm 112.7^{\mathrm{c}}$ & $462.3 \pm 58.1^{\mathrm{a}}$ \\
$\mathrm{Mn}(\mu \mathrm{g} / \mathrm{L})$ & $705.0 \pm 96.8^{\mathrm{b}}$ & $905.7 \pm 142.7^{\mathrm{c}}$ & $32.8 \pm 11.3^{\mathrm{a}}$ & $8.4 \pm 1.7^{\mathrm{b}}$ \\
$\mathrm{Zn}(\mathrm{mg} / \mathrm{L})$ & $57.5 \pm 12.8^{\mathrm{b}}$ & $37.8 \pm 9.7^{\mathrm{a}}$ & $1.6 \pm 0.8^{\mathrm{a}}$ & $29.5 \pm 9.9^{\mathrm{a}}$ \\
$\mathrm{Pb}(\mu \mathrm{g} / \mathrm{L})$ & $7.3 \pm 2.3^{\mathrm{b}}$ & $8.9 \pm 1.8^{\mathrm{b}}$ & $11.6 \pm 4.3^{\mathrm{a}}$ & $2.8 \pm 1.4^{\mathrm{a}}$ \\
$\mathrm{Cd}(\mu \mathrm{g} / \mathrm{L})$ & $9.2 \pm 4.5^{\mathrm{b}}$ & $2.3 \pm 1.1^{\mathrm{a}}$ & $16.3 \pm 6.7^{\mathrm{bc}}$ \\
\hline
\end{tabular}

Values within rows with different superscript letters are significantly different from each other $(P<0.05)$

consumption and improves tissue oxygenation [23] and thus could raise the body's tolerance to the hypoxic environment in plateau areas. Higher vitamin E levels in milk from yaks raised at higher altitudes would be helpful to the local population consuming yak's milk, because higher altitudes are deficient in oxygen. In addition, the vitamin A and vitamin E content in yak's milk was higher than that in cow's milk.

The content of the water-soluble vitamins $B_{1}$ (thiamin), $\mathrm{B}_{2}$ (riboflavin), and $\mathrm{C}$ (ascorbic acid) in milk from yaks raised at different altitudes is shown in Table 2 . The content of vitamin $B_{1}$ and vitamin $B_{2}$ was significantly higher in milk from yaks raised at $3,215 \mathrm{~m}$ than at 4,340 or $5,410 \mathrm{~m}$. These two vitamins play important roles in different metabolic processes, such as the development of tissues and the synthesis of corticoids in the human body [24]. The daily recommended intake for vitamin $B_{1}$ and vitamin $B_{2}$ in China is $2.0 \mathrm{mg}$ and $2-4 \mathrm{mg}$, respectively, for adults. Therefore, a $1 \mathrm{~L}$ serving of yak's milk can meet the $B_{1}$ and vitamin $B_{2}$ needs for adults. The content of vitamin $\mathrm{C}$ in milk from yaks raised at lower altitudes was higher than those at higher altitudes.

3.3. Macro-, Micro-, and Toxic Mineral Elements. The concentrations of toxic mineral elements in yak and cow milk are shown in Table 3. The concentrations of $\mathrm{Pb}$ in yak's milk obtained at $3,215,4,340$, and $5,410 \mathrm{~m}$ were $10.7 \pm 4.5,2.3$ \pm 1.1 , and $1.6 \pm 0.8 \mu \mathrm{g} / \mathrm{L}$, respectively. The concentrations of Cd in yak's milk obtained at 3,215, 4,340, and 5,410 m were $36.2 \pm 12.5,14.4 \pm 5.8$, and $11.6 \pm 4.3 \mu \mathrm{g} / \mathrm{L}$, respec- tively. In the Codex Alimentarius Commission, the maximum permissible concentration of $\mathrm{Pb}$ and $\mathrm{Cd}$ in all samples is $20 \mu \mathrm{g} / \mathrm{L}$ and $500 \mu \mathrm{g} / \mathrm{L}$, respectively. Thus, the content of both $\mathrm{Pb}$ and $\mathrm{Cd}$ in milk from yaks raised at different altitudes did not exceed the maximum permissible limit. In addition, the $\mathrm{Pb}$ and $\mathrm{Cd}$ content in yak's milk was higher at lower altitudes. The presence of $\mathrm{Pb}$ and $\mathrm{Cd}$ in milk is closely associated with the environment, including atmospheric sedimentation, waste disposal, and motor exhaust $[11,12]$. In the present study, the $3,215 \mathrm{~m}$ altitude regions are more industrialized and urbanized than the other regions at higher altitudes. Therefore, attention should be paid to possible toxicological risks in more industrialized and urbanized regions.

The concentrations of macroelements ( $\mathrm{Ca}, \mathrm{P}, \mathrm{Na}, \mathrm{K}$, and $\mathrm{Mg}$ ) in milk from yaks raised at different altitudes are shown in Table 3. There was no significant statistical difference in the $\mathrm{Ca}, \mathrm{P}, \mathrm{Na}, \mathrm{K}$, and $\mathrm{Mg}$ concentrations in milk obtained from yaks raised at different altitudes, although the concentrations were all much higher than those in cow's milk (except for $\mathrm{Na})$. The microelement content $(\mathrm{Cu}, \mathrm{Fe}, \mathrm{Mn}$, and $\mathrm{Zn}$ ) in milk from yaks raised at different altitudes showed different trends. The concentration of $\mathrm{Zn}$ in milk from yaks raised at different altitudes showed no statistical difference, whereas the $\mathrm{Mn}$ and Fe concentrations in milk from yaks raised at 3,215 $\mathrm{m}$ were lower than those raised at higher altitudes. However, the concentration of $\mathrm{Cu}$ was markedly higher in milk from yaks raised at 3,215 $\mathrm{m}$ than 
at higher altitudes. The recommended dietary intake for $\mathrm{Cu}$, $\mathrm{Fe}, \mathrm{Mn}$, and $\mathrm{Zn}$ is $700-900,800-1,800,1,900-2,300$, and $8,000-11,000 \mu \mathrm{g} / \mathrm{kg}$ body weight [25]. Our data indicated that yak's milk cannot meet the needs for these four microelements for adults.

\section{Conclusions}

At higher altitudes, significantly higher vitamin A and vitamin E content was observed in yak's milk, whereas the opposite was observed for vitamin $\mathrm{B}_{1}$ and vitamin $\mathrm{B}_{2}$. There was no significant statistical difference in the $\mathrm{Ca}, \mathrm{P}, \mathrm{Na}, \mathrm{K}$, and $\mathrm{Mg}$ concentrations in milk from yaks raised at different altitudes. The concentration of $\mathrm{Zn}$ in milk from yaks raised at different altitudes showed no statistical difference, whereas the $\mathrm{Mn}$ and $\mathrm{Fe}$ concentrations in milk from yaks raised at $3215 \mathrm{~m}$ were lower than those raised at higher altitudes. $\mathrm{The} \mathrm{Pb}$ and $\mathrm{Cd}$ concentrations were markedly higher in milk from yaks raised at 3,215 $\mathrm{m}$ than at higher altitudes.

\section{Data Availability}

The data used to support the findings of this study are available within the manuscript.

\section{Consent}

There are no human subjects, and informed consent is applicable.

\section{Conflicts of Interest}

The authors declared no potential conflicts of interest with respect to the research, authorship, and/or publication of this article.

\section{Acknowledgments}

The authors disclosed receipt of the following financial support for the research, authorship, and/or publication of this article: this study was supported by the Natural Science Foundation of Tibet Autonomous Region (766660029), the Central Government Supports the Development of Local Colleges and Universities in Tibet (503178004), and the Key Laboratory of Food Science and Engineering, Education Department of Tibet Autonomous Region.

\section{References}

[1] R. J. Long, D. G. Zhang, X. Wang, Z. Z. Hu, and S. K. Dong, "Effect of strategic feed supplementation on productive and reproductive performance in yak cows," Preventive Veterinary Medicine, vol. 38, no. 2-3, pp. 195-206, 1999.

[2] X. Guo, R. Long, M. Kreuzer et al., "Importance of functional ingredients in yak milk-derived food on health of Tibetan nomads living under high-altitude stress: a review," Critical Reviews in Food Science and Nutrition, vol. 54, no. 3, pp. 292-302, 2014.
[3] H. Li, Y. Ma, J. Xiang et al., "Comparison of the immunogenicity of yak milk and cow milk," European Food Research and Technology, vol. 233, no. 4, pp. 545-551, 2011.

[4] L. Yang, Z. Li, X. Gu, F. Chi, and Y. Zhu, "Synergistic effect of heating $\mathrm{pH}$ and transglutaminase on the gelation kinetics and texture of yak skim milk gels," Journal of Food Quality, vol. 2021, Article ID 6676518, pp. 1-7, 2021.

[5] J. Luo, L. Liu, T. Liu et al., "Simulated_in vitro_infant gastrointestinal digestion of yak milk fat globules: a comparison with cow milk fat globules," Food Chemistry, vol. 314, article 126160, 2020.

[6] P. Wang, H. Liu, P. Wen, H. Zhang, H. Guo, and F. Ren, "The composition, size and hydration of yak casein micelles," International Dairy Journal, vol. 31, no. 2, pp. 107-110, 2013.

[7] H. Zhang, J. Xu, J. Wang et al., "A survey on chemical and microbiological composition of kurut, naturally fermented yak milk from Qinghai in China," Food Control, vol. 19, no. 6, pp. 578-586, 2008.

[8] Q. Sheng, J. Li, M. S. Alam, X. Fang, and M. Guo, "Gross composition and nutrient profiles of Chinese yak (Maiwa) milk," International Journal of Food Science \& Technology, vol. 43, no. 3, pp. 568-572, 2008.

[9] Y. S. Peng, M. A. Brown, J. P. Wu, L. X. Wei, J. L. Wu, and D. Z. Sanbei, "Fatty acid profile in milk fat from Qinghai plateau yak at different altitudes and parities," The Professional Animal Scientist, vol. 24, no. 5, pp. 479-487, 2008.

[10] G. X. Cui, F. Yuan, A. A. Degen et al., "Composition of the milk of yaks raised at different altitudes on the QinghaiTibetan Plateau," International Dairy Journal, vol. 59, pp. 29-35, 2016.

[11] R. Norouzirad, J.-R. González-Montaña, F. Martínez-Pastor et al., "Lead and cadmium levels in raw bovine milk and dietary risk assessment in areas near petroleum extraction industries," Science of the Total Environment, vol. 635, pp. 308-314, 2018.

[12] A. M. S. Meshref, W. A. Moselhy, and N. E. Y. Hassan, "Heavy metals and trace elements levels in milk and milk products," Journal of Food Measurement and Characterization, vol. 8, no. 4, pp. 381-388, 2014.

[13] X. F. Chi, G. Y. Zhang, Y. Q. Yang, and F. Z. Hu, "Essential trace and toxic element levels in Tibetan yak's milk collected from Qinghai, China," Spectroscopy Letters, vol. 49, no. 7, pp. 477-481, 2016.

[14] H. Li, Y. Ma, Q. Li et al., “The chemical composition and nitrogen distribution of Chinese yak (Maiwa) milk," International Journal of Molecular Sciences, vol. 12, no. 8, pp. 4885-4895, 2011.

[15] Determination of Fat in Foods for Infants and Young Children, Milk and Milk Products, Ministry of Health of the People's Republic of China, Beijing, China, 2010.

[16] Determination of Fructose, Glucose, Sucrose, Maltose and Lactose in Food, Ministry of Health of the People's Republic of China, Beijing, China, 2016.

[17] Determination of VitaminA, D and E in Food, The National Health and Family Planning Commission, 2016.

[18] S. Albala'-Hurtado, M. T. Veciana-Nogue's, M.'. IzquierdoPulido, and A. Marine'-Font, "Determination of watersoluble vitamins in infant milk by high-performance liquid chromatography," Journal of Chromatography A, vol. 778, no. $1-2$, pp. 247-253, 1997. 
[19] "Determination of vitamin C in foods for infants and young children, milk and milk products," Ministry of Health of the People's Republic of China, Beijing, China, 2010.

[20] H. Li, Y. Ma, A. Dong et al., "Protein composition of yak milk," Dairy Science \& Technology, vol. 90, no. 1, pp. 111-117, 2010.

[21] E. Kondyli, M. C. Katsiari, and L. P. Voutsinas, "Variations of vitamin and mineral contents in raw goat milk of the indigenous Greek breed during lactation," Food Chemistry, vol. 100, no. 1, pp. 226-230, 2007.

[22] X. S. Guo, L. M. Ding, R. J. Long et al., "Changes of chemical composition to high altitude results in _Kobresia littledalei_ growing in alpine meadows with high feeding values for herbivores," Animal Feed Science and Technology, vol. 173, no. 3-4, pp. 186-193, 2012.

[23] T. Jafari, A. A. Fallah, M. Bahrami, and Z. Lorigooini, "Effects of pomegranate peel extract and vitamin $\mathrm{E}$ on oxidative stress and antioxidative capacity of hemodialysis patients: a randomized controlled clinical trial," Journal of Functional Foods, vol. 72, p. 104069, 2020.

[24] R. San José Rodriguez, V. Fernández-Ruiz, M. Cámara, and M. C. Sánchez-Mata, "Simultaneous determination of vitamin $\mathrm{B}_{1}$ and $\mathrm{B}_{2}$ in complex cereal foods, by reverse phase isocratic HPLC-UV," Journal of Cereal Science, vol. 55, no. 3, pp. 293299, 2012.

[25] D. Bakircioglu, N. Topraksever, S. Yurtsever, M. Kizildere, and Y. B. Kurtulus, "Investigation of macro, micro and toxic element concentrations of milk and fermented milks products by using an inductively coupled plasma optical emission spectrometer, to improve food safety in Turkey," Microchemical Journal, vol. 136, pp. 133-138, 2018. 